\title{
Interest in Learning of Indonesian Students with Online Gaming Addiction in The Academic Learning Process
}

\author{
Yanuar Fahrizal' ${ }^{1}$, Nurul Faiga ${ }^{1}$
}

1 Program Studi Keperawatan, Fakultas Kedokteran dan Ilmu Kesehatan, Universitas Muhammadiyah Yogyakarta

\section{Article Info}

\section{Article History:}

Submitted: Nov $25^{\text {th }}, 2020$

Accepted: Jan 19th, 2021

Published: Feb $13^{\text {th }}, 2021$

\section{Keywords:}

student; online game addiction; academic learning

\begin{abstract}
Student interest in learning has been declining due to the increasing number of distractions. Interest is one of the important factors contributing to one's desire and motivation to satisfy curiosity. As the times evolve, many things affect student interest in learning; one of which is smartphones equipped with the internet that promotes the ease of performing activities. Smartphones and the internet offer online games that can be accessed by anyone to play at any time, which can trigger online gaming addiction. The study aims to examine the interest in learning of nursing students who are addicted to online games. This study employed a qualitative method with a phenomenological approach. Data were collected through interviews, observations and documentation. The participants of the study were five students recruited using a snowball sampling method. Data were analyzed using Giorgi method. Results showed that interest in learning of students with online gaming addiction in the academic learning process varies. This can be seen through three emerging themes: student gaming behaviour, changes in students after online gaming, and the learning process of students with addiction to online games. It can be concluded that students' online game behaviour is influenced by impulsivity that changes student behaviour and leads to addiction.
\end{abstract}

\section{PENDAHULUAN}

Minat sangat mempengaruhi keinginan dan motivasi rasa ingin tahu seseorang. Faktor pendukung hasil belajar adalah minat dan motivasi [1]. Banyak hal yang dapat mempengaruhi minat dan konsentrasi belajar; Salah satunya adalah kemajuan pesat dari smartphone yang diakui sebagai fasilitator terbaik dalam memenuhi kebutuhan dan keinginan. Ponsel cerdas memudahkan kinerja banyak aktivitas; mereka dapat memfasilitasi transaksi, jual beli, edukasi dan kegiatan bermanfaat lainnya $[2,3]$.

Jumlah pengguna smartphone dunia tumbuh dari 2,1 miliar pada 2016 menjadi lebih dari 2,5 miliar pada 2019[4]. Indonesia memiliki jumlah pengguna smartphone tertinggi di Asia Tenggara dengan total 92 juta unit pada 2019 [5]. Banyaknya masyarakat Indonesia yang menggunakan smartphone didorong oleh

\footnotetext{
Corresponding author:

Yanuar Fahrizal yanuarfahrizal@umy.ac.id

Media Keperawatan Indonesia, Vol 4 No 1, February 2021

e-ISSN: 2615-1669

ISSN: 2722-2802

DOI: $\underline{10.26714 / \mathrm{mki} .4 .1 .2021 .36-46}$
} 
fitur berkemampuan internet mereka. Data Asosiasi Penyelenggara Jasa Internet Indonesia menunjukkan bahwa 49,52\% pengguna internet di Indonesia berusia 1934 tahun; lebih dari 50\% mengakses internet melalui smartphone mereka; dan $54,13 \%$ tercatat menggunakan smartphone untuk bermain game online [6].

Game online telah membawa konsekuensi di banyak negara. Amerika Serikat dan China melaporkan bahwa dua warganya meninggal setelah bermain game online non-stop selama lebih dari 20 jam [7]. Dengan adanya kejadian tersebut, Organisasi Kesehatan Dunia pada tahun 2018 menyatakan bahwa kecanduan game merupakan gangguan kesehatan mental dan dimasukkan dalam International Statistical Classification of Disease (ICD) versi terbaru pada tahun 2018. [8]. Selain kecanduan, game online berkontribusi pada penurunan minat belajar seseorang. Permainan online yang berlebihan adalah gangguan terbesar dan dapat merusak konsentrasi seseorang [9]. Jika ditelisik lebih jauh, hal-hal itu terkait. Seseorang yang melakukan dua hal atau lebih kemungkinan besar akan kehilangan konsentrasi. Hal ini menunjukkan adanya gap antara ekspektasi dan kenyataan yang harus dikaji.

Penelitian ini bertujuan untuk mengetahui minat belajar mahasiswa keperawatan yang kecanduan game online.

\section{METODE}

Penelitian ini merupakan penelitian kualitatif dengan pendekatan fenomenologi. Pendekatan tersebut digunakan untuk menguji minat belajar mahasiswa dengan kecanduan game online.

Penelitian dilakukan di program studi ilmu keperawatan UMY pada bulan Februari 2020 dengan merekrut 7 peserta dengan kriteria inklusi yaitu mahasiswa aktif keperawatan UMY yang sudah enam bulan bermain game online di smartphone.
Teknik pengambilan sampel menggunakan snowball sampling dilakukan dengan merekrut informan kunci yang kemudian membantu peneliti dalam menentukan peserta selanjutnya.

Variabel penelitian adalah pengalaman mahasiswa kecanduan game online. Data dikumpulkan melalui wawancara mendalam. Instrumen penelitian adalah peneliti yang dilengkapi dengan lembar wawancara, lembar observasi, dan lembar dokumentasi. Data dianalisis dengan menggunakan metode Giorgi (1985), yaitu metode membaca seluruh hasil, mengklasifikasikan pernyataan peserta dan menghubungkannya dengan peserta lain, serta mengelompokkan pernyataan tersebut ke dalam tingkatan yang lebih spesifik.

\section{HASIL}

Studi ini menghasilkan tiga tema, yaitu: 1) perilaku game online mahasiswa; 2) perubahan mahasiswa setelah bermain game online; dan 3) proses belajar mahasiswa dengan kecanduan game online.

\section{Perilaku bermain game online mahasiswa}

1. Tahapan permainan online

Tahap awal permainan online dijelaskan oleh pernyataan peserta berikut:

“... Ketika saya masih di sekolah menengah
saya pikir. Bagaimanapun, saya sudah mulai
bermain sejak COC versi 2 atau 3 keluar." (P2)
“... Saya mengetahui tentang warung internet
ketika saya masih di sekolah menengah. Itu
pertama kalinya saya bermain game online."
(P3)
"Ya, karena saya memiliki warung internet."
(P4)
"Saya mulai bermain game online pada
semester ketiga." (P5)

Alasan bermain game online ditunjukkan oleh pernyataan peserta berikut ini: 
"Saya secara otomatis bergabung juga. Tanpa diduga, saya kecanduan karena bermain dengan teman itu sangat menyenangkan." (P1)

"Saya sangat bersenang-senang saat bermain game online dengan teman-teman saya." (P2)

"Ya, game online lebih menyenangkan karena kita harus bermain bersama." (P3)

"Game online lebih menyenangkan karena kita bisa memberi tahu teman kita", "ada sesuatu di belakangmu", "jangan pergi ke sana", dan" bomnya ada di sini. " (P4)

"Game online lebih baik karena kita bisa terhubung dengan orang lain." (P5)

\section{Ketersediaan akses permainan online}

Berikut adalah pernyataan peserta yang menunjukkan sumber informasi tentang game online:

“. dari teman, saat game sedang booming." (P2)

“... itu juga dari teman, tapi orang yang berbeda." (P2)

“... Aku mempelajarinya dari ibuku.” (P4)

“... Saya diperkenalkan dengan permainan oleh teman-teman saya. Awalnya saya tidak tahu seperti apa permainan itu. " (P5)

Pernyataan peserta di bawah ini menunjukkan alat yang digunakan untuk bermain game online.

“... Menggunakan ponsel cerdas.” (P2)

"Saya bermain game online di ponsel cerdas saya." (P3)

"Saya menggunakan laptop atau ponsel cerdas saya." (P4)

"Saya dulu lebih sering bermain di PC, tapi sekarang saya menggunakan ponsel cerdas saya." (P5)

Jenis permainan online yang dimainkan para peserta dapat dilihat dari keterangannya di bawah ini:

“... Saat itulah game bernama COC sangat populer." (P1)

"RPG adalah jenis game 3D. Itu bisa diarahkan dari berbagai sudut. Ini adalah game petualangan dan memiliki banyak misi. Ada klan juga ... "(P2)

"FPS ... ini adalah game battle royale. Ini terutama tentang penembakan di satu arena.
Pemain harus bertahan hidup. Jadi, ini adalah game bertahan hidup. " (P3)

"Saya bermain PB dan XShot. Mereka tentang menembak. Saya juga memainkan game AyoDance." (P4)

"Saya biasanya bermain Mobile Legends. Ini seperti ada lima pemain dalam satu tim dan lawannya adalah satu kelompok. Lalu kami memilih pahlawan kami untuk bertarung satu sama lain. " (P5)

3. Emosi mahasiswa saat bermain game online

Emosi yang dirasakan mahasiswa saat memenangkan game online diuraikan dari pernyataan peserta sebagai berikut:

“... Ketika saya menang, saya merasa bahagia.” (P1)

“... Saat pertandingan menyenangkan dan saya menang banyak, saya merasa bahagia." (P3)

“... Saya merasa senang saat memenangkan pertandingan." (P5)

Perasaan ketika mahasiswa kalah game online ditunjukkan oleh pernyataan peserta berikut ini:

"Saat kalah, saya merasa bingung dan sedikit stres. Ada tekanan juga. " (P1)

“... Ketika kalah, saya merasa frustrasi dan putus asa." (P2)

"Saya merasa kesal. Saya tidak suka jika saya telah memainkan game selama berjam-jam dan saya kalah. " (P5)

4. Sensasi saat bermain game online

Sensasi saat bermain game online di luar pembelajaran di kelas dijelaskan dari pernyataan peserta berikut ini.

\footnotetext{
"Oh, aku harus fokus karena rasanya aku punya ujian." (P1)

“... Ini terasa seperti saya melakukan olahraga favorit saya. Begitulah cara saya menjelaskannya. " (P2)
}

Sensasi bermain game online selama pembelajaran di kelas diilustrasikan oleh pernyataan peserta di bawah ini. 
"Ini menyenangkan seperti adrenalin. Saya takut ketahuan sementara pada saat yang sama saya ingin terus bermain game. " (P2)

“... Gugup seperti aku ingin melihat apakah aku punya nyali, tapi aku juga takut ketahuan." (P3)

"Saya benar-benar menyukai permainan ini, sangat tertarik padanya. Bahkan, saya selalu memainkannya di semua kelas. "

Saya takut, tapi saya tidak tahu. (P5)

5. Durasi bermain game online

Waktu maksimum yang dibutuhkan mahasiswa untuk bermain game online ditunjukkan oleh pernyataan peserta sebagai berikut:

"Saya bisa bermain game online maksimal enam sampai sepuluh jam." (P1)

"Waktu terlama... hampir 20 jam." (P2)

“Waktu terlama? 18 jam. ” (P3)

"Maksimal 24 jam, tapi beberapa waktu lalu saya tidak tidur selama dua hari." (P4)

"Saat bermain dalam grup, saya bermain dari jam 10 hingga jam 1." (P5)

Waktu minimum yang dibutuhkan mahasiswa untuk bermain game online ditunjukkan oleh pernyataan peserta di bawah ini.

"Minimal dua jam." (P1)

"Sekali atau dua kali jika saya tidak salah. Itu hanya sekitar 10 sampai 20 menit. " (P2)

Sekarang sekitar dua jam. (P3)

"Saat aku sedang tidak mood, mungkin hanya setengah jam." (P4)

"Dua jam." (P5)

Waktu rata-rata untuk bermain game online pada hari kerja ditunjukkan oleh pernyataan peserta berikut.

“Sekitar 4-5 jam sehari." (P2)

"Total 5-6 jam.” (P3)

"Saya biasanya bermain dari 2 hingga 3 jam." (P5)

Rata-rata waktu bermain game online pada hari libur ditunjukkan oleh pernyataan peserta sebagai berikut.
"Sampai 10 jam." (P2)

"Sekitar 8 jam." (P3)

"Pada hari libur, ketika saya ingin begadang, saya akan begadang." (P3)

"Di hari libur, saya bisa bermain sampai subuh." (P5)

\section{Perubahan pada mahasiswa setelah bermain game online}

\section{Perubahan kognitif}

Hasil wawancara menunjukkan bahwa terjadi perubahan kognitif pada mahasiswa yang bermain game online. Subtema ini membahas beberapa kategori, yaitu perubahan kemampuan berbahasa dan berpikir logis.

Peningkatan kemampuan berbahasa dapat dibuktikan dengan pernyataan peserta berikut ini.

"Yah, saya belajar lebih banyak kata dalam bahasa Inggris melalui game online daripada film atau membaca." (P3)

"Saya mendapat info dari teman dari Thailand, Filipina." (P4)

Perbaikan dalam berpikir logis ditunjukkan oleh pernyataan peserta di bawah ini.

Saya menjadi lebih logis, lebih aktif. (P3)

"Mungkin karena permainannya, saya harus belajar tentang strategi $A, B, C$, dan D. Saya perlu berpikir lebih keras."

"Menjadi lebih... memahami lebih banyak tentang strategi." (P5)

2. Perubahan afektif

Wawancara dengan peserta menunjukkan hasil bahwa mereka mengalami perubahan pada aspek afektif. Perubahan tersebut dapat dibuktikan dengan kategori berikut dan pernyataan peserta.

Perubahan emosi terlihat dari pernyataan peserta berikut ini. 
"Sangat marah. Saya sangat kesal ketika saya bersenang-senang bermain game online, dan seseorang menelepon. Saya sangat marah." (P1)

“... Banyak orang yang berbicara, mengucapkan kata-kata kasar, jadi aku merasa kesal." (P2)

"Saat saya bermain dan orang-orang membuat banyak suara, saya menggedor pintu mereka. Sungguh. Itu berbahaya." (P4)

Perubahan perilaku dijelaskan oleh pernyataan peserta sebagai berikut.

Aku menjadi lebih dingin. (P1)

"Terkadang saya membuat keputusan yang salah." (P4)

"Karena saya terlalu fokus pada permainan saya, saya sering mengabaikan teman-teman saya." (P5)

\section{Perubahan sosial}

Hasil penelitian menunjukkan bahwa mahasiswa yang bermain game online juga mengalami perubahan sosial. Kategori ini menghasilkan perubahan dalam kemampuan bersosialisasi.

Perubahan kemampuan bersosialisasi dibuktikan dengan pernyataan peserta sebagai berikut.

"Saya jarang berkomunikasi dengan orang lain karena saya sering bermain game." (P1)

"Hubungan saya dengan teman saya yang lain semakin buruk karena teman bermain saya." (P3)

"Saya adalah tipe orang yang sulit berteman, tapi sepertinya lebih baik berteman di dunia nyata. Kalau di dunia game, teman hanya bisa diajak main. "(P4)

Saya jarang bergaul. Kadang-kadang ketika saya diundang untuk nongkrong, saya bahkan lebih peduli dengan game online. (P5)

4. Perubahan rutinitas

Hasil penelitian menunjukkan bahwa partisipan mengalami perubahan dalam rutinitasnya, seperti pola tidur, pola makan, dan aktivitas lainnya.
Perubahan pola tidur ditunjukkan oleh pernyataan peserta berikut ini.

\author{
Aku kurang tidur. (P1) \\ "Kadang-kadang saya tidur jam 2. Terkadang \\ saya tidak tidur sama sekali. " (P2) \\ "Aku tidur, tapi agak berantakan saat bermain \\ game." (P3) \\ "Jadwal tidur saya berubah. Kadang-kadang \\ saya tidur jam 3 atau 4. " (P4) \\ "Pola tidur saya berubah. Saya hanya bisa tidur \\ jam 3. " (P5) \\ Perubahan kebiasaan makan \\ ditunjukkan oleh pernyataan peserta \\ sebagai berikut.
}

"Saya makan malam di tengah malam." (P1)

"Saya makan lebih sedikit. Terkadang hanya sekali makan. " (P2)

"Waktu makan tidak teratur. Aku akan makan saat aku sedang mood untuk itu. " (P3)

"Terkadang saya hanya makan dalam satu hari. Terkadang saya terpikir, "Oh, benar, saya belum makan." (P4)

"Kebiasaan makan saya telah berubah." (P5)

Perubahan pada kegiatan lain ditunjukkan oleh pernyataan peserta di bawah ini.

Ini menjadi kacau balau. (P1)
"Ini semakin fisik. Saya menjadi lebih lamban."
(P2)

"Rencana bermain bulu tangkis atau basket sering dibatalkan karena adanya permainan online." (P3)

"Nah, bermain game online terasa seperti Anda tidak memiliki kehidupan karena Anda terlalu fokus pada game." (P4)

"Berbicara tentang aktivitas saya yang telah berubah... saya rasa semua aktivitas saya telah berubah." (P5)

\section{Perubahan minat belajar}

Hasil penelitian menunjukkan bahwa peserta mengalami perubahan minat belajar, namun ada juga yang tidak. Dengan demikian, subtema ini membahas dua kategori yang berbeda: perubahan dan tidak ada perubahan minat belajar. 
Perubahan minat belajar ditunjukkan oleh pernyataan peserta berikut ini.

"Ada beberapa perubahan. Saya menjadi lebih tertarik pada game. " (P2)

"Ya, karena minat pada game online lebih tinggi." (P3)

"Karena saya tidak bisa bermain game untuk waktu yang singkat. Itu sebabnya saya jarang belajar." (P5)

Tidak ada perubahan dalam minat belajar yang ditunjukkan oleh pernyataan peserta di bawah ini.

"Biasa saja. Saya memiliki minat yang sama sebelum dan sesudah ". (P1)

"Sama saja. Saya tidak suka belajar. " (P4)

\section{Proses belajar mahasiswa yang bermain game online}

1. Gangguan selama proses pembelajaran

Hasil wawancara menunjukkan bahwa partisipan teralihkan oleh beberapa hal seperti media sosial dan game online pada saat mereka belajar. Berikut adalah pernyataan peserta tentang gangguan tersebut.

Gangguan saat belajar akibat game online ditunjukkan oleh pernyataan peserta berikut ini.

"Ada banyak godaan seperti media sosial dan terutama game."

"Saya sering tergoda seperti saya benar-benar ingin bermain, tapi saya harus belajar." (P4)

"Yang paling mengganggu adalah game." (P5)

Gangguan saat belajar akibat media sosial tergambar dari pernyataan peserta di bawah ini.

"Saat belajar, saya lebih sering memikirkan media sosial saya seperti Instagram dan YouTube daripada game." (P1)

"... media sosial. Kalau tidak, saya menonton TV. " (P3)
2. Alokasi waktu belajar

Hasil wawancara menunjukkan bahwa waktu yang dialokasikan untuk belajar dipengaruhi oleh permainan online. Subtema ini membahas dua kategori yang ditunjukkan oleh pernyataan peserta yang mengungkapkan waktu maksimum dan minimum yang mereka alokasikan untuk belajar.

Waktu maksimum yang dialokasikan untuk belajar dijelaskan oleh pernyataan peserta di bawah ini.

"Bekerja bersama dalam kelompok bisa
memakan waktu sekitar 2-3 jam." (P2)

“Tidak terlalu lama. Maksimal satu jam. ” (P3)

Dua jam dari jam 8 sampai jam 10. (P5)

Waktu minimum yang dialokasikan untuk belajar ditunjukkan oleh pernyataan peserta sebagai berikut.

"Hanya sampai 30 menit untuk mengerjakan
pekerjaan rumah." (P2)
"Mungkin satu jam. Setelah itu, saya bermain
game lagi." (P5)

3. Perasaan saat belajar

Hasil penelitian menunjukkan bahwa peserta merasa senang saat mengalami proses pembelajaran. Hal ini dibuktikan dengan pernyataan para peserta saat wawancara.

Perasaan bahagia selama proses
pembelajaran ditunjukkan
pernyataan peserta berikut ini.

"Senang, ya, karena di kampus, tempat yang bagus untuk belajar. Saya sangat malas ketika saya tinggal di rumah kost. " (P1)

"Lebih nyaman belajar di kampus. Saya bisa belajar bersama teman-teman saya. " (P4)

4. Perasaan saat tidak belajar

Hasil penelitian menunjukkan bahwa partisipan tidak memiliki perasaan saat tidak belajar. Subtema ini membahas dua 
kategori perasaan: lega dan khawatir saat tidak belajar.

Rasa cemas saat tidak belajar ditunjukkan oleh pernyataan peserta sebagai berikut.

“... Jika saya tidak belajar, saya merasa khawatir. Saya berpikir tentang seperti apa ujiannya nanti. " (P2)

"Saya merasa tidak enak karena memikirkan orang tua saya yang telah membiayai sekolah saya, jadi saya harus belajar." (P5)

Perasaan lega dan pasrah saat tidak belajar tergambar dari pernyataan peserta berikut ini.

"Saya merasa lega seperti tidak ada beban." (P3)

"Saya mendapat nilai rendah di MCQ, dan saya menyadari saya tidak belajar, jadi saya menerima konsekuensinya." (P4)

\section{PEMBAHASAN}

\section{Perilaku bermain game online mahasiswa}

Hasil penelitian menunjukkan bahwa perilaku bermain game online mahasiswa bervariasi dan dapat diklasifikasikan menjadi beberapa sub tema: 1) tahapan game online; 2) ketersediaan akses game online; 3) emosi saat bermain game online; 4) sensasi saat bermain game online; dan 4) durasi bermain game online.

Hasil penelitian menunjukkan bahwa mahasiswa melewati tahapan sebelum akhirnya bermain game online. mahasiswa awalnya memainkan game offline sebelum beralih ke game online karena dianggap lebih seru dan bisa dimainkan bersama orang lain. Interaksi antar pemain diperlukan selama permainan online [10]. Perkembangan zaman modern telah memungkinkan game online menjadi lebih realistis, yang mengarah pada daya tarik orang-orang yang lebih kuat untuk game online. Hasilnya, semakin banyak orang yang tertarik untuk mengenal game offline dan online.
Hasil penelitian menunjukkan bahwa ketersediaan akses bermain game online meningkatkan keinginan seseorang untuk bermain game. Akses tersebut mencakup sumber informasi berharga tentang game online, seperti orang tua dan teman sebaya. Orang tua yang bermain game online lebih cenderung melibatkan anak-anak untuk bermain game daripada orang tua yang tidak bermain game online [11]. Jenis akses lain yang dapat membantu perkembangan permainan online adalah ketersediaan peralatan yang dapat digunakan di mana saja dan kapan saja. Perkembangan teknologi sering kali diabaikan dan dianggap game hanya dapat dimainkan di komputer, padahal game online dapat diakses melalui smartphone. [12]. Jenis permainan yang memberikan banyak pilihan juga dapat mendorong lebih banyak orang untuk memainkan permainan online. Game online dengan genre MMOBA (Massively Multiplayer Online Battle Arena) sangat populer di kalangan remaja [13]. Remaja biasanya tidak stabil, agresif, dan bersemangat akan sesuatu yang baru [14]. Munculnya hal-hal baru bisa menjadi awal bagi seseorang untuk memiliki ketertarikan pada sesuatu. Dalam hal ini, lingkungan memiliki peran penting dalam pertumbuhan anak.

Hasil penelitian menunjukkan bahwa mahasiswa merasakan emosi saat bermain game online. mahasiswa merasa bersemangat saat memenangkan permainan dan frustrasi saat kalah dalam permainan. Emosi dikendalikan oleh otak dengan pelepasan dopamin [15]. Dopamin adalah neurotransmitter otak yang mengatur perasaan bahagia [16]. Bermain game dapat mengubah bagian otak yang mengontrol perhatian dan impuls dengan melepaskan dopamin [17]. Kebahagiaan dari bermain game bersifat dangkal atau non materi yang meliputi terpenuhinya keinginan akan pengakuan, kekuasaan, dan kebanggaan atas suatu prestasi. [18]. Seseorang mencapai tujuan bermain game online saat memenangkan game. Dia akan diakui oleh lawannya. Ini akan 
mengaktifkan impuls otak yang nantinya diterjemahkan menjadi kebahagiaan atau kesedihan.

Siswa juga merasakan sensasi saat bermain game online. Seseorang yang menghabiskan banyak waktu untuk bermain game online dapat memiliki kecenderungan untuk menjadi kecanduan [19]. Salah satu masalah yang mengindikasikan adiksi adalah pencarian sensasi yang berkaitan erat dengan keinginan seseorang untuk merasakan sensasi baru [20]. Dalam kaitan ini, game online memiliki elemen yang dapat memicu sensasi baru bagi pemainnya dan dapat menyebabkannya terus bermain game untuk mencari sensasi yang belum pernah ia alami sebelumnya.

Hasil penelitian menunjukkan bahwa lamanya waktu yang dihabiskan mahasiswa untuk bermain game online bervariasi. Waktu minimal yang dihabiskan untuk bermain game online adalah 30 menit, sedangkan waktu maksimalnya adalah 2 hari non stop. Seseorang yang menghabiskan waktu lama dengan intensitas tinggi untuk melakukan aktivitas tertentu dapat digolongkan menjadi kecanduan [21]. Salah satu aspek dari kecanduan adalah toleransi, yaitu proses bermain game secara berulang-ulang dan terus bertambah durasinya [22]. Seseorang yang sangat tertarik pada sesuatu kemungkinan akan menambah waktu yang dialokasikan untuk melakukannya, yang menunjukkan bahwa dia telah kecanduan.

\section{Perubahan pada mahasiswa setelah bermain game online}

Hasil penelitian menunjukkan bahwa perubahan terjadi ketika seseorang memainkan game online untuk jangka waktu yang lama. Perubahan tersebut meliputi aspek kognitif, afektif, dan sosial serta rutinitas dan minat belajar.

Perubahan kognitif dapat dilihat pada kemampuan menggunakan bahasa asing dan logika. Ada enam tahapan taksonomi
Bloom: pengetahuan, pemahaman, penerapan, analisis, sintesis, dan evaluasi [23]. Seseorang yang terlatih untuk berpikir dan merencanakan strategi akan lebih cenderung memiliki pemikiran logis yang lebih baik daripada seseorang yang tidak terbiasa menggunakan logika secara intensif. [24]. Game online memungkinkan pemain untuk mempelajari banyak hal tentang game tersebut, yang pada gilirannya dapat memengaruhi kemampuannya untuk memahami instruksi. Ini menunjukkan bahwa seseorang dapat secara signifikan meningkatkan pemikiran logis seseorang jika sering dihadapkan pada masalah atau tantangan.

Perubahan juga terjadi pada aspek afektif yang terkait dengan kecerdasan emosional. Mirip dengan kecerdasan kognitif, kecerdasan afektif memiliki tahapannya sendiri yaitu menerima, menanggapi, menilai, mengorganisasi, dan mengkarakterisasi oleh suatu nilai. [23]. Pada tingkat kecerdasan tertinggi, seseorang akan memiliki nilai-nilai yang berkaitan dengan aspek pribadi serta emosi mental dan sosial yang mempengaruhi kepribadiannya. [25]. Berbagai hal dapat dengan mudah mempengaruhi keadaan emosi seseorang. Perubahan emosi lebih sering terlihat pada orang yang menggunakan internet secara berlebihan [26]. Berbagai perubahan dapat terjadi pada seseorang yang bermain game online secara berlebihan. Berbagai konten tidak menyenangkan pada game online sering kali mendorong orang untuk melakukan tindakan yang tidak tepat sehingga menimbulkan perilaku negatif.

Hasil penelitian menunjukkan bahwa perubahan sosial juga dapat terjadi pada seseorang yang memainkan game online. Kemampuan seseorang untuk bersosialisasi di dunia nyata menurun sebagai akibat dari permainan online yang berlebihan. Seseorang yang menghabiskan waktu lebih lama untuk bermain game online dapat mengalami kendala dalam melakukan 
interaksi dengan teman-temannya [27]. Orang yang sering kehilangan kemampuan mengatur waktu untuk bermain game online cenderung mengabaikan dunia nyata [28]. Hal ini disebabkan oleh perubahan sirkuit otak akibat perilaku pencarian kesenangan yang dilakukan secara terus menerus dan menjadi kompulsif [29]. Dunia virtual game online bisa memicu kebahagiaan. Namun, semakin sering kebahagiaan diterjemahkan oleh otak, semakin tinggi kemungkinan perubahan terjadi di sirkuit otak yang memengaruhi peningkatan neurobiologi. Akibatnya seseorang bisa kehilangan banyak kesempatan untuk bersosialisasi dan belajar dari lingkungannya.

Perubahan lain yang dialami mahasiswa adalah perubahan dalam rutinitasnya. Perubahan paling umum yang disebabkan oleh game online adalah pola makan dan tidur [30]. Perubahan ini terjadi karena ketidakmampuan seseorang untuk mengontrol impuls, emosi, atau keinginan [31]. Kurangnya pengendalian diri dapat mengakibatkan perubahan urutan prioritas seseorang [32]. Seseorang biasanya suka melakukan sesuatu yang tidak membutuhkan energi tinggi. Beberapa orang beranggapan bahwa bermain game online di smartphone dapat menciptakan sensasi yang mirip dengan berolahraga, sehingga menimbulkan keyakinan bahwa tidak perlu melakukan aktivitas fisik.

Minat belajar juga dapat berubah setelah seseorang memainkan game online dalam waktu yang lama. Hal ini disebabkan oleh alokasi waktu dan minat terhadap game online yang lebih besar dibandingkan dengan pembelajaran sehingga mengakibatkan prokrastinasi akademik. Itu adalah perilaku menunda kegiatan akademik, termasuk belajar dan menyelesaikan tugas, dan melakukan hal lain yang tidak terkait dengan hal-hal akademik sebagai gantinya [33]. Semakin besar minat seseorang pada hal-hal yang dapat memicu kecanduan, semakin rendah pula minatnya untuk belajar.

\section{Proses belajar mahasiswa dengan kecanduan game online}

Hasil tersebut mengangkat tema yang menggambarkan proses belajar mahasiswa yang kecanduan game online. Hal itu terlihat dari gangguan saat belajar, alokasi waktu belajar, dan perasaan terhadap belajar.

Gangguan yang paling umum saat belajar adalah permainan online dan media sosial. Banyak gangguan yang disebabkan oleh kemajuan teknologi yang dapat mempengaruhi proses belajar seseorang, seperti smartphone atau gadget yang dapat terkoneksi dengan internet. [34]. Pemanfaatan visual dalam kemajuan teknologi bisa menjadi gangguan terbesar.

Berdasarkan hasil belajar, mahasiswa mengalokasikan waktu 1-3 jam untuk belajar, namun tidak rutin belajar pada waktu yang konsisten. Waktu belajar yang lebih sedikit dan jam belajar yang tidak konsisten mengakibatkan ketidakmampuan seseorang untuk mengingat apa yang telah dipelajari [35]. Kemajuan teknologi bisa menyebabkan seseorang menjadi malas [36]. Waktu belajar yang lebih sedikit terkait erat dengan lingkungan seseorang. Seseorang akan cenderung memilih hal-hal yang disukai dan berlebihan.

Perasaan campur aduk bisa timbul saat belajar. Beberapa mahasiswa sering kali merasa lega ketika tidak memiliki kebutuhan untuk belajar. Namun, mereka mengkhawatirkan ujian. Hasil belajar seseorang dipengaruhi oleh minat dan motivasi belajar [37]. Hal-hal yang dengan mudah dapat memotivasi seseorang adalah orientasi harapan masa depan serta kesenangan dan keinginan [38]. Perasaan seseorang terhadap belajar dipengaruhi oleh motivasi dan keinginan untuk belajar.

\section{SIMPULAN}

Perilaku bermain game online pada mahasiswa mulai terbentuk ketika berbagai 
hal mendorong dan menyebabkan mahasiswa secara impulsif berusaha hingga kecanduan bermain game online. Setelah bermain game online, mahasiswa mengalami perubahan yang meliputi perubahan kognitif, perubahan afektif, perubahan sosial, perubahan rutinitas, dan perubahan minat belajar. Proses belajar mahasiswa dengan kecanduan game online dapat dilihat melalui berbagai gangguan, waktu belajar yang sedikit, dan perasaan campur aduk terhadap belajar.

\section{UCAPAN TERIMA KASIH}

Kami mengucapkan terima kasih kepada LP3M Universitas Muhammadiyah Yogyakarta yang telah memberikan hibah penelitian sesuai dengan SK Nomor 030 / PEN-LP3M / I / 2020.

\section{REFERENSI}

[1] Aritonang K. Minat dan Motivasi dalam Meningkatkan Hasil Belajar Siswa. J Pendidik Penabur 2008:11-21.

[2] Juraman SR. Pemanfaatan Smartphone Android Oleh Mahasiswa Ilmu Komunikasi dalam Mengakses Informasi Edukatif 2014;III.

[3] Nusarika LAK, Purnami NM. Pengaruh Presepsi Harga, Kepercayaan dan Orientasi Belanja terhadap Niat Beli Secara Online (studi pada Produk Fashion Online di Kota Denpasar). E-Jurnal Manaj Unud 2015;4:2380-406.

[4] Statista. Number of Smartphone Users Worldwide from 2014 to 2020 (in billions) 2017.

[5] Katadata. Proyeksi Pengguna Smartphone di Asia Tenggara 2016-2019 2016.

[6] APJI. Infografis Penetrasi \& Perilaku Pengguna Internet Indonesia. Teknopreuner 2017;2018:Hasil Survey.

[7] Jaya ES. WHO tetapkan kecanduan game sebagai gangguan mental, bagaimana "gamer" Indonesia bisa sembuh? The Converstation 2018.

[8] World Health Organization. 11th revision of the International Classification of Diseases (ICD-11). 11th ed. 2018.

[9] Karcy A, Waliyanti E. The Correlation Between Intensity of Using Smartphone with
Learning Concentration among Nursing Student Universitas Muhammadiyah Yogyakarta 2017;2.

[10] Rosdiana E. Perilaku Adiksi Remaja pada Game Online di Surabaya. Universitas Airlangga, 2017.

[11] Schneider LA, King DL, Delfabbro PH. Family factors in adolescent problematic Internet gaming : A systematic review. J Behav Addict 2017;6:321-33.

https://doi.org/10.1556/2006.6.2017.035.

[12] Masya H, Candra DA. Faktor-Faktor yang Mempengaruhi Perilaku Gangguan Kecanduan Game Online pada Peserta Didik Kelas X di Madrasah Aliyah Al Furqon Prabumulih Tahun Pelajaran 2015/2016 2016;03:153-69.

[13] Guno DC. Gambaran Perilaku Kecanduan Game Online pada Anak Usia Sekolah di Wilayah Kecamatan Magetan. Universitas Muhammadiyah Surakarta, 2018.

[14] Agustriyana NA, Suwanto I. Fully Human Being pada Remaja Sebagai Pencapaian Perkembangan Ientitas. J Bimbing Konseling Indones 2017;2:9-11. https://doi.org/24778370 .

[15] Stepnicki P, Kondej M, Kaczor AA. Current Concepts and Treatments of Schizophrenia 2018.

https://doi.org/10.3390/molecules230820 87.

[16] Zaini M. Asuhan Keperawatan Jiwa Masalah Psikososial di Pelayanan Klinis dan Komunitas. In: Yulianti T, editor. 1. 1st Editio, Yogyakarta: Deepublisher; 2019, p. 45.

[17] Weinstein A, Livny A, Weizman A. New Developments in Brain Research of Internet and Gamming Disorder. Neurosci Behav Rev 2017;75:312-30.

https://doi.org/https://doi.org/10.1016/j.n eubiorev.2017.01.040.

[18] Fatkhullah M. Komodifikasi Kebahagiaan Semu dalam Game Online ( Studi tentang Konstruksi dan Komodifikasi Kebahagiaan dalam Bermain Game pada Gamer Dewasa yang Telah Berkeluarga). J Komunitas $2015 ; 4$.

[19] Sumomulyo Y, Buniyani K. Hubungan Antara Sensation Seeking dan Kecanduan Game Online Pada Mahasiswa. Universitas Mercubuana Yogyakarta, 2019.

[20] Hu J, Zhen S, Yu C, Zhang Q, Zhang W, Harris YR. Sensation Seeking and Online Gaming Addiction in Adolescents: A Moderated Mediation Model of Positive Affective Associations and Impulsivity. Front Psychol

Yanuar Fahrizal / Interest in Learning of Indonesian Students with Online Gaming Addiction in The Academic Learning Process 
2017;8:1-8.

https://doi.org/10.3389/fpsyg.2017.00699.

[21] Suryanto RN. Dampak Positif dan Negatif Permainan Game Online Dikalangan Pelajar. Jom FISIP 2015;2:1-15.

[22] Lemmens JS, Valkenburg PM, Peter J. Development and validation of a game addiction scale for adolescents. Media Psychol 2009;12:77-95. https://doi.org/10.1080/15213260802669 458.

[23] Demirel Ş, Çetinkaya S. The Analysis of Limit Questions Asked in Univercity Selection and Placemet Exams Between 1997-2013 According to The Bloom's Taxonomy and Cognitive Levels of Elementary Mathematics Preservice Theacher. Turkish Stud 2016;11:267-82.

https://doi.org/10.1016/S09670637(02)00146-2.

[24] Kwak KH, Hwang HC, Kim SM, Han DH. Comparison of Behavioral Changes and Brain Activity between Adolescents with Internet Gaming Disorder and Student Pro-Gamers 2020;11.

[25] Ugur H, Constantinescu PM, Stevens MJ. Selfawareness and personal growth: Theory and application of bloom's taxonomy. J Educ Res 2015:89-110.

https://doi.org/10.14689/ejer.2015.60.6.

[26] Kant R. Relationship of Internet Addiction With Emotional Intelligence Among Youths. GESJ Educ Sci Psychol 2019.

[27] Febriandari D, Nauli FA. Hubungan Kecanduan Bermian Game Online Terhadap Identitas Diri Remaja 2016;4:50-6.

[28] Novrialdy E. Kecanduan Game Online Pada Remaja: Dampak dan Pencegahanya. Bul Psikol 2019;27.

[29] Uhl GR, Koob GF, Cable J. The neurobiology of addiction. Ann N Y Acad Sci 2019;1451:5-28. https://doi.org/10.1111/nyas.13989.

[30] Surbakti K. Pengaruh Game Online Terhadap
Remaja. J Curere 2017;01.

[31] Sela A, Berger J, Kim J. How Self-Control Shapes the Meaning of Choice. Oxford Univ Press Behalf J Consum Res Inc 2017;44. https://doi.org/10.1093/jcr/ucx069.

[32] King D, Delfabro P. Internet Gaming Disorder. 1st ed., Australia: Academic Press; 2018, p. 294.

[33] Kurniawan DE. Pengaruh Intensitas Bermain Game Online Terhadap Perilaku Prokrastinasi Akademik Pada Mahasiswa Bimbingan dan Konseling Universitas PGRI Yogyakarta. J Konseling GUSJIGANG 2017;3:97-103.

[34] Jannah N, Nirwana H. Hubungan Kecanduan Game dengan Motivasi Belajar Siswa dan Implikasinya Terhadap Bimbingan dan Konseling. Konselor 2015;4.

[35] Davis D, Kizilcec RF, Hauff C, Houben G. Scaling Effective Learning Strategies: Retrieval Practice and Long-Term Knowledge Retention in M00Cs. J Learn Anal 2018;5:21-41.

https://doi.org/http://dx.doi.org/10.18608 /jla.2018.53.3.

[36] Ali Z, Dwikurnaningsih Y. Pengaruh dari Dampak Game Online Terhadap Motivasi Belajar pada Siswa Kelas VIII SMP Kristen 2 Salatiga Tahun Ajaran 2018/2019 2019;X:122-33.

[37] Ricardo, Meilani RI. Impak minat dan motivasi belajar terhadap hasil belajar siswa ( The impacts of students ' learning interest and motivation on their learning outcomes ). J Pendidik Manaj Perkantoran 2017;2:188201.

[38] Taylan H. The Factors that Affect Language Learning Motivation of Adult Learners Who Learn English as A Foreign Langage in Turkish University Context. Int Period Lang Lit Hist Turkish or Turkic 2017;12:411-30. https://doi.org/http://dx.doi.org/10.7827/ TurkishStudies.11395. 